\title{
Evaluation of Nitric Oxide Concentrations in Preeclampsia and Normal Pregnancy
}

\author{
SALMAAKTER, FIROZA BEGUM, SHARMINABBASI
}

\begin{abstract}
:
During pregnancy Nitric oxide is one of the most important relaxing factors for myometrium and also in the control of blood flow in uterus and placenta. Nitric oxide is generated by endothelial type II nitric oxide synthase (NOS) and acts as a vasodilator.
\end{abstract}

Objective:To investigate the level of nitric oxide (NO) production in pregnancies complicated by preeclampsia and in normal pregnancy.

Materials and Methods: A case control study was undertaken in Department of Gynaecology and Obstetrics of Bangabandhu Sheikh Mujib Medical University (BSMMU), from january to july 2014. The study population was pregnant women having preeclampsia and normal pregnancy who attended the OPD Department of Obstetrics and Gynecology in BSMMU between 29 to 40 weeks of gestation. As because of transient and volatile nature of nitric oxide, it was unsuitable to measure the nitric oxide level by conventional method. However, two stable break down product, nitrate $\left(\mathrm{NO}_{3}^{-}\right)$and nitrate $\left(\mathrm{NO}_{2}^{-}\right)$could be easily detected by sprectophototric means. Nitrate $\left(\mathrm{NO}_{2}^{-}\right)$was first converted to Nitrite $\left(\mathrm{NO}_{3}^{-}\right)$by reduction process using cadmium. Then concentration was measured by using Griess reagent in U$\checkmark$ sprectophototric machine. This procedure was done in the Biochemistry Department, Dhaka University.

Results: The mean nitrite level was found $18.37 \pm 3.64 \mathrm{~mol} / \mathrm{L}$ in case group and $25.57 \pm 2.11 \mathrm{~mol} /$ $L$ in control group, which was significantly $(p<0.05)$ higher in control group. The mean serum creatinine level was found $1.19 \pm 0.28 \mathrm{mg} / \mathrm{dl}$ in case group and $0.65 \pm 0.1 \mathrm{mg} / \mathrm{dl}$ in control group. The mean serum creatinine level was significantly $(p<0.05)$ higher in case groups. Nitrite level had no correlation with onset of hypertension $(r=-0.006 ; p=0.966)$, onset of proteinuria ( $r=0.071 ; p=0.623)$, systolic blood pressure $(r=0.012 ; p=0.933)$, diastolic blood pressure $(r=-0.159 ; p=0.269)$ and urine protein $(r=0.047, p=0.748)$.

Conclusion: As pregnancy progressed there was a decrease in plasma nitric oxide levels in preeclampsia. Urine uric acid to creatinine ratio increased with the decrease in nitric oxide levels and can be used as a marker for preeclampsia.

Keywords: Pregnancy,preeclampsia,nitric oxide.

\section{Introduction:}

Pre-eclampsia is a serious complication of pregnancy. Prevalence of preeclampsia in developing countries ranges from $1.8 \%$ to $16.7 \% .^{1}$ It is identified by increased blood pressure and protein in the urine, but women often suffer no symptoms initially. It can, through constriction of the blood vessels in the placenta, interfere with nutrition and oxygen supply to the baby, thus restricting the foetal growth and causing the baby to be born too soon ${ }^{1}$. Nitric oxide

1. Registrar, Department of Obstetrics and Gynecology Anwer Khan Modern Medical College Hospital

2. Head,Fetomaternal unit Department of Obstetrics and GynaecologyBangabandhu Sheikh Mujib Medical University (BSMMU)

3. Assistant Professor,Department of Obstetrics and Gynecology Anwer Khan Modern Medical College Hospital

Address of Correspondence: Dr. Salma Akter, Registrar, Department of Obstetrics and Gynecology, Anwer Khan Modern Medical College Hospital. Phone: 01712420558 
drugs, like glycerol trinitrate, or their precursors, like L-arginine, may play a role in helping to prevent preeclampsia through their action in relaxing blood vessel walls. [2] Serum nitrite levels were higher in preeclamptic women $(34.11 \pm 141 / 4 \mathrm{~mol} / \mathrm{l}, \mathrm{P}=0.04)$, lower in chronic hypertensive women $(19.56 \pm 6.46$ $1 / 4 \mathrm{~mol} / \mathrm{l}, \mathrm{P}=0.04$ ) and similar in women with gestational hypertension $(26.97 \pm 9.441 / 4 \mathrm{~mol} / \mathrm{l})$ in comparison to the control group (25.37 $\pm 7.241 / 4 \mathrm{~mol} / \mathrm{l})$. [3] Circulating levels of nitrite are decreased in patients with preeclampsia. $^{4}$

The numerous studies on the multifunctional nature of the nitric oxide (NO) have suggested the wide variety of functions mediated by this molecule in vital processes in cardiovascular, nervous, gastrointestinal, urogenital system and during immunological reactions. In Hudicek-Martincic, Kusan-Jukic and Salihagic-Kadic (2004) review the results of experiments carried out on animal models, as well as the results of clinical studies considering the role of $\mathrm{NO}$ and its metabolites during pregnancy and delivery.[5] During pregnancy NO is one of the most important relaxing factors of myometrium, and also no less important in the control of blood flow in uterus and placenta.

\section{Materials and Methods}

A Case control study was undertaken in the Department of Obstetrics and Gynaecology, Bangabandhu Sheikh Mujib Medical University (BSMMU), Dhaka from january to july 2016. On one hundred pregnant women having preeclampsia and normal pregnancy after 28 weeks of gestation. A total of 50 pregnancies complicated by preeclampsia and 50 normal pregnancy who attended outdoor and in-patient Department of Obstetrics and Gynaecology, Bangabandhu Sheikh Mujib Medical University (BSMMU), Dhaka (Six months) were enrolled in this study. Inclusion Criteria includespregnant women (Both primi and multi) presented with preeclampsia at third trimester (29 to 40 weeks) as case and primigravida and multigravida with normal BP, no proteinuria and without any other systemic or endocrine disorder as control. Purpose and procedure of the study were discussed with the patient who fulfills the inclusion criteria. Written consent was taken from those who agreed to be included in the study. All the variables of interest were collected by detail history, clinical examination and biochemical investigation was recorded on the pre-designed data collection sheet. All information was kept confidential.

From each patient $4 \mathrm{ml}$ venous blood was drawn. Then it was kept at $4^{0} \mathrm{C}$ approximately for one hour. After that, blood was centrifuged at $3000 \mathrm{xg}$ for 10 minutes. As because of transient and volatile nature of NO, it is unsuitable to measure the NO level by conventional method. However, two stable break down product, nitrate $\left(\mathrm{NO}_{3}{ }^{-}\right)$and nitrate $\left(\mathrm{NO}_{2}{ }^{-}\right)$can be easily detected by sprectophototric means. Nitrate $\left(\mathrm{NO}_{2}^{-}\right)$is first converted to Nitrite $\left(\mathrm{NO}_{3}^{-}\right)$by reduction process using cadmium. Then concentration is measured by using Griess reagent in U-V sprectophototric machine. This procedure was done in the Biochemistry Department, Dhaka University.

The research protocol is approved by the committee of the instalation (Local Ethical Committee).Statistical analyses were carried out by using the Statistical Package for Social Sciences version 16.0 for Windows (SPSS Inc., Chicago, Illinois, USA). P values $<0.05$ were considered as statistically significant.

\section{Results:}

Age, socio-economic status, gestational age and parity were similar in both cases and control table I-IV.

Table-I

Distribution of the study patients according to age $(n=100)$

\begin{tabular}{|c|c|c|c|c|c|}
\hline \multirow[t]{2}{*}{$\begin{array}{l}\text { Age } \\
\text { (years) }\end{array}$} & \multicolumn{2}{|c|}{$\begin{array}{l}\text { Case } \\
(n=50)\end{array}$} & \multicolumn{2}{|c|}{$\begin{array}{l}\text { Control } \\
(n=50)\end{array}$} & \multirow[t]{2}{*}{$P$ value } \\
\hline & $\mathrm{n}$ & $\%$ & $\mathrm{n}$ & $\%$ & \\
\hline$\leq 20$ & 3 & 6.0 & 6 & 12.0 & \\
\hline $21-25$ & 24 & 48.0 & 35 & 70.0 & \\
\hline $26-30$ & 16 & 32.0 & 9 & 18.0 & \\
\hline$>30$ & 7 & 14.0 & 0 & 0.0 & \\
\hline Mean $\pm S D$ & \multicolumn{2}{|c|}{$25.76 \pm 5.04$} & \multicolumn{2}{|c|}{$24.9 \pm 3.09$} & $0.916^{n s}$ \\
\hline $\begin{array}{l}\text { Range } \\
\text { (min-max) }\end{array}$ & \multicolumn{2}{|c|}{ 17-35 } & \multicolumn{2}{|c|}{$18-28$} & \\
\hline
\end{tabular}

Table-II

Distribution of the study patients according to socio economic status $(n=100)$

\begin{tabular}{lcccccc}
\hline $\begin{array}{l}\text { Socio economic } \\
\text { status }\end{array}$ & \multicolumn{2}{c}{$\begin{array}{c}\text { Case } \\
(\mathrm{n}=50)\end{array}$} & & \multicolumn{2}{c}{$\begin{array}{c}\text { Control } \\
(\mathrm{n}=50)\end{array}$} & P value \\
\cline { 2 - 3 } & $\mathrm{n}$ & $\%$ & & $\%$ & \\
\hline Lower class & 45 & 90.0 & 47 & 94 & $0.357^{\mathrm{ns}}$ \\
Middle class & 5 & 10.0 & 3 & 6 & \\
\hline
\end{tabular}


Table-III

Distribution of the study patients according to gestational age $(n=100)$

\begin{tabular}{|c|c|c|c|c|c|}
\hline \multirow[t]{2}{*}{$\begin{array}{l}\text { Gestational } \\
\text { age (weeks) }\end{array}$} & \multicolumn{2}{|c|}{$\begin{array}{l}\text { Case } \\
(\mathrm{n}=50)\end{array}$} & \multicolumn{2}{|c|}{$\begin{array}{l}\text { Control } \\
(\mathrm{n}=50)\end{array}$} & \multirow[t]{2}{*}{ Pvalue } \\
\hline & $\mathrm{n}$ & $\%$ & $\mathrm{n}$ & $\%$ & \\
\hline Preterm ( $\leq 36$ weeks) & 41 & 82.0 & 38 & 76.0 & \\
\hline Term (37-40 weeks) & 9 & 0.0 & 12 & 24.0 & \\
\hline Postdated ( $>40$ weeks) & 0 & 0.0 & 0 & 0.0 & \\
\hline Mean $\pm S D$ & \multicolumn{2}{|c|}{$32.98 \pm 2.61$} & \multicolumn{2}{|c|}{$33.74 \pm 3.31$} & $0.205^{\mathrm{ns}}$ \\
\hline Range (min-max) & \multicolumn{2}{|c|}{ 28-38 } & \multicolumn{2}{|c|}{ 28-39 } & \\
\hline
\end{tabular}

Table-IV

Distribution of the study patients according to gravida $(n=100)$

\begin{tabular}{|c|c|c|c|c|c|}
\hline \multirow[t]{2}{*}{ Gravida } & \multicolumn{2}{|r|}{ Case $(n=50)$} & & Control $(n=50)$ & \multirow[t]{2}{*}{$P$ value } \\
\hline & & $\%$ & & $\%$ & \\
\hline Primi & 27 & 54.0 & 21 & 42.0 & $0.229^{n s}$ \\
\hline Multi & 23 & 46.0 & 29 & 58.0 & \\
\hline
\end{tabular}

Table-V

Distribution of the study patients according to Nitrite level $(n=100)$

\begin{tabular}{lccl}
\hline & $\begin{array}{c}\text { Case } \\
(\mathrm{n}=50) \\
\text { Mean } \pm S D\end{array}$ & $\begin{array}{c}\text { Control } \\
(\mathrm{n}=50) \\
\text { Mean } \pm S \mathrm{~S}\end{array}$ & P value \\
\hline Nitrite level $(\mu \mathrm{mol} / \mathrm{L})$ & $18.37 \pm 3.64$ & $25.57 \pm 2.11$ & $0.001^{\mathrm{s}}$ \\
Range (min-max) & $15.4-28.3$ & $22.8-29.5$ & \\
\hline
\end{tabular}

Table $\mathrm{V}$ shows nitrite level of the study patients. It was observed that the mean nitrite level was found $18.37+3.64 \mathrm{~mol} / \mathrm{L}$ in case group and $25.57+2.11 \mathrm{~mol} /$ $L$ in control group. Nitrite level was significantly lower among the pre-eclamtic group.

\section{Table-VI}

Distribution of the study patients according to onset of hypertension, proteinuria (case group $=50$ )

\begin{tabular}{lcc}
\hline & Mean \pm SD & Min-Max \\
\hline Onset of Hypertension (weeks) & $29.8 \pm 1.9$ & $28-33$ \\
Onset of proteinuria (weeks) & $29.9 \pm 2.1$ & $28-33$ \\
\hline
\end{tabular}

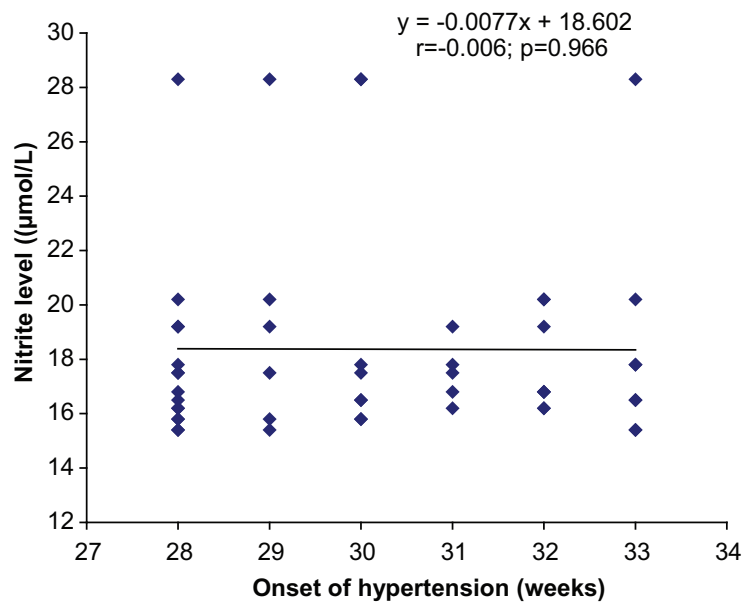

Fig.-1: Scatter diagram showing no correlation ( $r=-$ $0.006 ; p=0.966$ ) between onset of hypertension with nitrite level.

Mean weeks of gestation of onset of hypertension and proteinuria were similar (table $-\mathrm{VI}$ ) and severe proteinuria was found in $52 \%$ cases of pre-eclampsia (table-VII)..

\section{Table VII}

Distribution of the study patients according to urine protein (case group, $n=50$ )

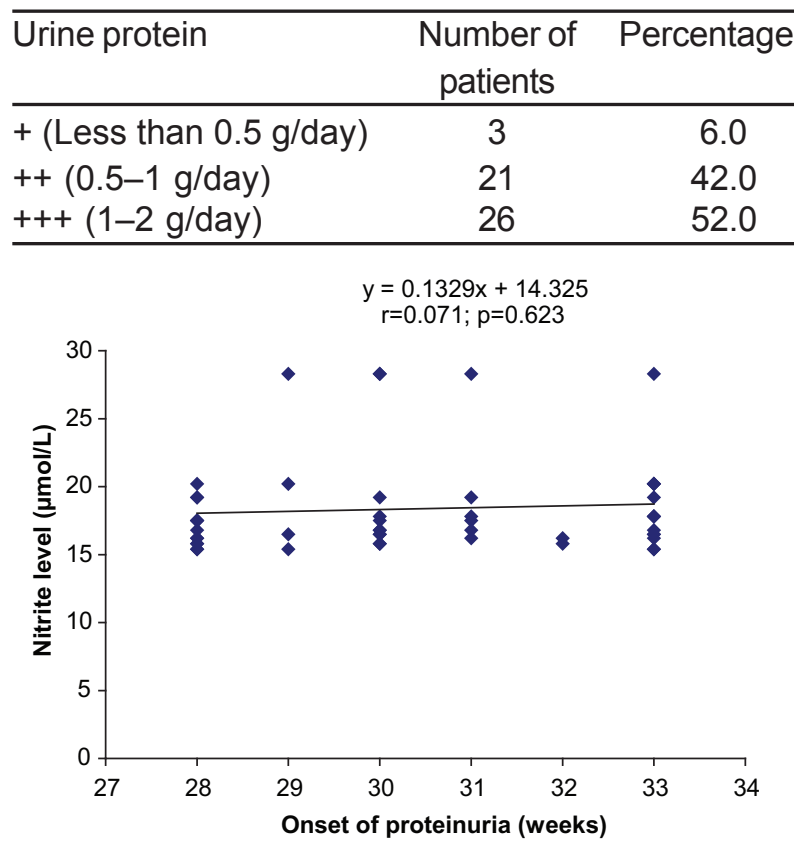

Fig.-2: Scatter diagram showing no correlation $(r=0.071 ; p=0.623)$ between onset of proteinuria with nitrite level.

Scatter diagrams show that there was no correction of nitrate level with onset level of hypertension or proteinuria (Fig $1 \& 2$ ) 
Table-VIII

Distribution of the study patients according to serum creatinine $(n=100)$

\begin{tabular}{|c|c|c|c|c|c|}
\hline \multirow[t]{2}{*}{ Serum creatinine $(\mathrm{mg} / \mathrm{dl})$} & \multicolumn{2}{|c|}{ Case $(n=50)$} & \multicolumn{2}{|c|}{ Control $(n=50)$} & \multirow[t]{2}{*}{ P value } \\
\hline & $\mathrm{n}$ & $\%$ & $\mathrm{n}$ & $\%$ & \\
\hline$<0.6-1.2(\mathrm{mg} / \mathrm{dl})$ normal & 37 & 74.0 & 50 & 100.0 & \\
\hline$>1.2 \mathrm{mg} / \mathrm{dl}$ & 13 & 26.0 & 0 & 0.0 & \\
\hline $\begin{array}{l}\text { Mean } \pm S D \\
\text { Range (min-max) }\end{array}$ & \multicolumn{2}{|c|}{$1.19 \pm 0.28$} & \multicolumn{2}{|c|}{$0.65 \pm 0.1$} & $0.001^{\mathrm{s}}$ \\
\hline
\end{tabular}

In case group, $37(74.0 \%)$ patients had serum creatinine level $<0.6-1.2 \mathrm{mg} / \mathrm{dl}$ level and in control group all patients had urinary creatinine $0.6-1.2 \mathrm{mg} /$ $\mathrm{dl}$ level. The mean urine creatinine level was found $1.19+0.28 \mathrm{mg} / \mathrm{dl}$ in case group and $0.65 \pm 0.1 \mathrm{mg} / \mathrm{dl}$ in control group. The difference was statistically significant $(p<0.05)$ between two groups. (TableVIII)

\section{Discussion:}

Nitric oxide (NO) is related to gestational vasodilatation during pregnancy. Deficiency of or impaired responsiveness to NO has been reported to cause preeclampsia mentioned by Podjarny, Mandelbaum and Bernheim. ${ }^{6}$ Preeclampsia is characterized by increased systemic vascular resistance and contracted plasma volume. In parallel, the response to vasopressor agents is exaggerated. It can be assumed that these abnormalities are related to an imbalance in the synthesis of vasoactive agents and that the same is related to endothelial cell damage. ${ }^{7}$

This case control study was carried out with an aim to investigate the level of nitric oxide (NO) production in pregnancies complicated by preeclampsia and in normal pregnancy.

This study include 50 pregnant women with preeclampsia and 50 normal pregnancy who were attending inpatient and out patients Department of Obstetrics and Gynaecology in Bangabandhu Sheikh Mujib Medical University (BSMMU), Dhaka, during August 2013 to January 2014 were included in this study. Pregnant women both primigravida and multigravida presented with preeclampsia at third trimester (29 to 40 weeks) were considered as case. Primigravida and multigravida with normal BP, no proteinuria and without any other systemic or endocrine disorder were considered as control. Patient with known chronic renal disease, hepatic dysfunction, history of preexisting hyperlipidaemia, history of taking lipid-altering drug and subjects suffering from any other systemic or endocrine disorder were excluded from the study. The present study findings were discussed and compared with previously published relevant studies. ${ }^{8}$

In this present study it was observed that almost half $(48.0 \%)$ of the patient's age belonged to $21-25$ years in case group and $56.0 \%$ in control group. The mean age was found $25.76 \pm 5.04$ years varied

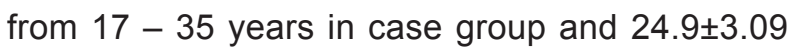
years varied from $18-28$ years in control group. The mean age difference was not significant $(p>0.05)$ between two groups. ${ }^{7}$ Sahu et al. (2011) showed the mean age was $26.0 \pm 4.7$ years and $25.0 \pm 3.6$ years in case and control group respectively, which is closely resembled with the current study. Hendler et al. (2005) observed the mean $( \pm S D$ )age was $21.3 \pm 5.9$ years and $19.1 \pm 4.0$ years in case and control respectively which is a little lower than the current study. ${ }^{9}$ On the other hand, Anim-Nyame et al. (2000) have showed the mean $( \pm$ SD)age was $29.3 \pm 3.2$ years and $31.7 \pm 3.5$ years in case and control respectively. ${ }^{10}$

In this current study it was observed that majority patients came from lower socio-economic family in both groups, which was $90.0 \%$ in case group and $94.0 \%$ in control group. The difference was not statistically significant $(p>0.05)$ between two groups. In this present study it was observed that $82.0 \%$ patients had preterm gestational age in case group and $76.0 \%$ in control group. The mean gestational age was found $32.98 \pm 2.61$ weeks varied from 28 38 weeks in case group and $33.74 \pm 3.31$ weeks varied from 28 - 39 weeks in control group. The difference was not statistically significant $(p>0.05)$ between two 
groups. Almost similar gestational age range was observed by Anim-Nyame et al. (2000), ${ }^{10}$ where they had 26 to 38 weeks of gestation in both groups. Hendler et al. (2005) observed higher mean gestational age in their study. ${ }^{9}$

The incidence of preeclampsia in the United States is estimated to range from $2 \%$ to $6 \%$ in healthy, nulliparous women. ${ }^{11}$ In this current study it was observed that in case more than half $(54.0 \%)$ patients were primi gravida and in control group majority $29(58.0 \%)$ patients had multi gravida. The difference was not statistically significant $(p>0.05)$ between two groups. $^{12}$

As seen in different studies, plasma nitric oxide levels in preeclampsia fall to one third the levels to that obtained in normal pregnancy and there was also a decrease in plasma nitric oxide levels in both cases and controls as pregnancy progressed. Probably suggesting that this change in nitric oxide levels could be important in the beginning of delivery and cervical maturation. Pregnancy is characterized by low plasma levels of Larginine because of increased transfer of amino acids to fetus mentioned by Domenench et al. (1986). ${ }^{13}$ Relative deficiency of the precursor in the presence of systolic endothelial damage may cause insufficient synthesis of the product that is nitric oxide as observed by Podjarny et al. (1994). ${ }^{6}$ To support this hypothesis, it has also been reported that administration of $L$ - arginine ameliorated a syndrome of intravascular coagulation resembling preeclampsia and administration of nitric oxide donors and nitric oxides inhibitors provides effective and safe management of complications of preeclampsia.[14] In this series it was observed that the mean nitrite level was found $18.37 \pm 3.64 \mu \mathrm{mol} / \mathrm{L}$ in case group and $25.57 \pm 2.11 \mu \mathrm{mol} / \mathrm{L}$ in control group. The mean nitrite level was significantly $(p<0.05)$ higher in control group. Choi et al. (2002) showed the mean nitric oxide concentration in preeclamptic women was $43.1 \pm 12.7 \frac{1}{4} \mathrm{M}$, which was significantly higher than in nonpregnant women $\left(23.8 \pm 7.1 \frac{1}{4} \mathrm{M}, \mathrm{p}<0.05\right)$. [8] The role of nitric oxide in preeclampsia is still uncertain. Lyall et al (1995) found that there was no significant difference in maternal serum nitrite concentrations between a control group and a preeclamptic group. ${ }^{15}$ Cameron et al. (1993) demonstrated that the plasma or urinary nitrate (or nitrite) level was increased during preeclampsia compared to normal gestation. ${ }^{16}$ Contrary to these results, in Choi et al. (2002) study, nitric oxide concentrations in preeclamptic women were significantly lower than those in the gestational agematched normal pregnant women, who showed no differences from preeclamptic women in serum ferritin levels. 8

Since preeclampsia is associated with reduced synthesis of vasodilators and increased synthesis of vasoconstrictors, researchers have sought to investigate possible therapeutic benefit for use of nitric oxide donors in treatment and prevention of preeclampsia. Animal data have shown that chronic nitric oxide blockade is associated with hypertension, proteinuria, and reductions in kidney function. Consistent with these observations, use of nitric oxide donors has shown benefit in a few human studies done by Chhabra et al. (2012). ${ }^{17}$ In one case a successful pregnancy followed use of nitric oxide donors in a patient with scleroderma who had had preeclampsia in a preceding pregnancy. However, until this is validated in large scale, prospective randomized studies use of these nitric oxide donors cannot be recommended in all patients. They should be considered in selected patients as mentioned by Larsen et al. (2012). ${ }^{18}$

In this present study it was observed that the mean onset of hypertension was found $29.8 \pm 1.9$ weeks and mean onset of proteinuria was $29.9 \pm 2.1$ weeks. In this current study it was observed that more than half $(52.0 \%)$ patients had $3+$ urine protein followed by $2+$ in $42.0 \%$ and $1+$ only in $6.0 \%$. In this present study it was observed that in case group, $74.0 \%$ patients had serum creatinine level $<0.6-1.2 \mathrm{mg} / \mathrm{dl}$ level and in control group all patients had 0.6-1.2 mg/dl level. The mean serum creatinine level was found $1.19 \pm 0.28$ $\mathrm{mg} / \mathrm{dl}$ in case group and $0.65 \pm 0.1 \mathrm{mg} / \mathrm{dl}$ in control group. The mean serum creatinine level was significantly $(p<0.05)$ higher in case groups. In this current study, it was observed that there were no correlation between onset of hypertension $(r=-0.006$; $p=0.966)$ and onset of proteinuria $(r=0.071 ; p=0.623)$ with nitrite level. There were also no correlation between systolic blood pressure $(r=0.012 ; p=0.933)$, 
diastolic blood pressure $(r=-0.159 ; p=0.269)$ and urine protein $(r=0.047, p=0.748)$ with nitrite level.

\section{Conclusion:}

This study was undertaken to investigate the level of nitric oxide (NO) production in pregnancies complicated by preeclampsia and in normal pregnancy and it was observed that deficiency of nitric oxide and increase in serum uric acid levels are related to preeclampsia. No association was found with onset of hypertension, onset of proteinuria, systolic blood pressure, diastolic blood pressure and urine protein. The decrease in nitric oxide levels with nitrite as proxy indicator can be used as a marker for preeclampsia.

\section{Reference:}

1. Osungbade KO, Ige OK. Public Health Perspectives of Preeclampsia in Developing Countries: Implication for Health System Strengthening J Pregnancy. 2011. Published online 2011 Apr 4. doi: 10.1155/2011/481095. https://www.ncbi.nlm.nih.gov/pmc/articles/ PMC3087154/

2. Meher S, Duley L. Cochrane Database of Systematic Reviews Nitric oxide for preventing pre eclampsia and its complications. https:// www.cochranelibrary.com/cdsr/doi/10.1002/ 14651858.CD006490/abstract

3. Bartha JL, Comino-Delgado R, Bedoya SJ. Maternal serum nitric oxide levels associated with biochemical and clinical parameters in hypertension in pregnancy. European Journal of Obstetrics \& Gynecology and Reproductive Biology. 1999; 82(2): 201-207

4. Seligman SP, Buyon JP, Clancy RM, Young BK, Abramson SB. The role of nitric oxide in the pathogenesis of preeclampsia. American Journal of Obstetrics and Gynecology. 1994; 171(4): 944-948

5. Hudicek-Martincic G., Kusan- Jukic M., Salihagic- Kadic A. Nitric oxide- an important signaling molecule in normal and pathological pregnancy. Lijecnicki Vjesnik, 2004 126(34),80-85.
6. Podjarny E, Mandelbaum A, Bernheim J. Does nitric oxide play a role in normal pregnancy andpregnancy-induced hypertension? Nephrol Dial Transplant (1994) 9: 1527-1540.

7. Roberts MJ, Taylor RN, Musci TJ. Preeclampsia: An endothelial cell disorder. American Journal of Obstetrics and Gynecology. 1989; 161(5), 1200-1204.

8. Choi, J.W., Im, M.W. and Pai, S.H. 2002. Nitric Oxide Production Increases during Normal Pregnancy and Decreases in Preeclampsia. Annals of Clinical \& Laboratory Science, 32(3), pp. 257-26

9. Hendler I, Blackwell SC, Mehta SH, Whitty JE., Russell, E., Sorokin, Y., Cotton, D.B. The level of leptin, adiponectin and resistin in normal weight, overweight and obsess pregnant women with and without preeclampsia. American Journal of Obstetrics and gynecology, 2005; 193, 979:983.

10. Anim-Nyame N, Sooranna SR, Steer PJ, Johnson MR. Longitudinal analysis of maternal plasma leptin concentrations during normal pregnancy and preeclampsia. Human Reproduction, 2000.15, 2033-2036.

11. Sibai BM. Diagnosis and Management of Gestational Hypertension and Preeclampsia. Obstetrics \& Gynecology. 2003; 102(10): 181192

12. Dutta, DC. Hypertensive disorder in pregnancy. In: Konar $\mathrm{H}$, editor. Textbook of obstetrics including perinatology and contraception. 6th ed. Calcutta: New Central book Agency Limited, 2011. 221-42.

13. Domenench M, Grupposo PA, Nishino VT, Susa JB, Schwartz R. Preserved fetal plasma amino acid concentration in presence of maternal hypoaminoacidemia. Pediatr Res, 1986(20); 1071-1076.

14. Maul H; Longo M; Saade GR; Garfield RE. Nitric Oxide and its Role During Pregnancy: From Ovulation to Delivery. Current Pharmaceutical Design, 2003;9(5):359-380. 
15. Lyall, F., Young, A., Greer, I.A. Nitric oxide concentrations are increased in the fetoplacental circulation in preeclampsia. Am J Obstet Gynecol. 1995;173: 714-718.

16. Cameron IT, van Papendorp CL, Palmer RMJ, Smith SK, Moncada S. Relationship between nitric oxide synthesis and increase in systolic blood pressure in women with hypertension in pregnancy. Hypertens Pregnancy, 1993;12: 85-92.
17. Chhabra, S., Tyagi, S., Bhavani, M. and Gosawi, M. 2012. Late postpartum eclampsia," Journal of Obstetrics and Gynaecology, 32(3), pp. 264266.

18. Larsen WI, Strong JE and Farley JH. Risk factors for late postpartum preeclampsia. Journal of Reproductive Medicine for the Obstetrician and Gynecologist. 2012;57(1: 35-38. 